 \\ (6LORIDA
}

EXTENSION

Institute of $\mathbf{F}_{\text {ood and }} \mathbf{A g r i c u l t u r a l} \mathbf{S}$ ciences

\section{Florida Crop/Pest Management Profile: Atemoya and Sugar Apple ${ }^{1}$}

Mark A. Mossler and O. Norman Nesheim²

\section{Production Facts}

- Atemoya (Annona squamosa x Annona cherimola) and sugar apple (Annona squamosa) are both deciduous trees of the Annonaceae. The plants are of tropical American origin and produce fruits that are similar. These two crops share other similarities in addition to fruit, such as environmental requirements and pest spectrum. For this reason, the survey questionnaire completed by atemoya and sugar apple growers grouped these two tropical fruits together $(1,2)$.

- The 1995-96 Florida production of atemoya was 64,000 pounds. At an average seasonal price of $\$ 4.00$ per pound and a packout of 80 percent, the crop was estimated to be worth $\$ 205,000$. The 1995-96 Florida production of sugar apple was 20,000 pounds. At an average seasonal price of $\$ 3.00$ per pound and a packout of 90 percent, the crop was estimated to be worth $\$ 54,000$ (3).

- The acreage of atemoya and sugar apple peaked in 1989-90 at 120 and 75 acres, respectively (3). Hurricane Andrew affected established trees, and as of 2000, acreage of atemoya and sugar apple was 10 and 15 acres, respectively (4).

- In 1995-96, the average yield for atemoya was 6,400 pounds per acre. This value was 1,000 pounds per acre for sugar apple (3).

- In 1995-96, 95 percent of atemoya was shipped out of Miami-Dade County. For sugar apple, this value was only 10

1. This document is CIR 417 one of a series of the Pesticide Information Office, Food Science and Human Nutrition Department, Florida Cooperative Extension Service, Institute of Food and Agricultural Sciences, University of Florida. For additional Information, contact the Pesticide Information Office, University of Florida, P. O. Box 110710, Gainesville, Fl 32611-0710, (352) 392-4721. Published: September 2002. Please visit the EDIS Web site at http://edis.ifas.ufl.edu

2. Mark A. Mossler, pest management information specialist. O. Norman Nesheim, Ph.D., professor and pesticide coordinator, Pesticide Information Office, Food Science and Human Nutrition Department, Cooperative Extension Service, Institute of Food and Agricultural Sciences, University of Florida, Gainesville, 32611-0710.

The use of trade names in this publication is solely for the purpose of providing specific information. UF/IFAS does not guarantee or warranty the products named, and references to them in this publication does not signify our approval to the exclusion of other products of suitable composition. All chemicals should be used in accordance with directions on the manufacturer's label.

The Institute of Food and Agricultural Sciences is an equal opportunity/affirmative action employer authorized to provide research, educational information and other services only to individuals and institutions that function without regard to race, color, sex, age, handicap, or national origin. For information on obtaining other extension publications, contact your county Cooperative Extension Service office. Florida Cooperative Extension Service / Institute of Food and Agricultural Sciences / University of Florida / Christine Taylor Waddill, Dean 
percent, owing to the fragile nature of this fruit (3).

- There are a number of atemoya cultivars which differ in fruit characteristics. Most sugar apple trees are grown from seedlings, although some "Seedless" varieties have been imported from Cuba and Brazil $(1,2)$.

\section{Production Regions}

Atemoya and sugar apple are grown exclusively in south Florida. In 2000, 70 percent of the atemoya production was located in MiamiDade County. For that same period, 100 percent of the sugar apple production was in this same county (3). The remaining atemoya acreage is primarily located in counties adjacent to MiamiDade County.

\section{Production Practices}

The atemoya tree is relatively small $(10 \mathrm{~m})$, with an open canopy. Leaves are elliptic, ovate, or lanceolate, and often variable in shape on the same tree. Leaf length is ten to $20 \mathrm{~cm}$ and width ranges from four to eight $\mathrm{cm}$. Flowers are three to four $\mathrm{cm}$ in diameter with three fleshy, pale, yellowish-green petals. They are borne singly or in clusters of two to three in axils of leaves on year-old wood or on new shoots. The main bloom period in Florida is May through June, with a minor bloom in August through September. The flowers are protogyrous, functioning first as female, then as male. Atemoya bears an aggregate fruit from five to six months after bloom that may weigh up to one pound. It is at first green, but becomes more light green or yellowish green upon maturity. The pulp is white, with a custardlike consistency and a sweet pleasant flavor. There are typically ten to 40 seeds per fruit (1).
The sugar apple tree is also small (5 m), with a rounded canopy and slender branches. Thin, lanceolate leaves range in length from six to ten $\mathrm{cm}$. The leaves are a dull, pale green with sparse hairs at flush, but become smooth at maturity. Flowers are about three $\mathrm{cm}$ in length and are produced singly or in clusters of two to four in late spring. The aggregate fruit produced is round, conical, or heart-shaped. The skin is thick and yellowish green. The pulp is creamy white and filled with numerous small dark seeds (2).

Most sugar apple trees grown in Florida are seedlings since there is little variability among them. When grafting is done, veneer grafting on custard apple (Anonna reticulata) is the preferred method. Shield budding also produces acceptable trees. A number of selections have been made from atemoya seedling populations. "Gefner" produces satisfactory fruit without hand pollination. Other varieties either split upon maturity or produce few fruit without hand pollination. Atemoya grown from seed are extremely variable. Superior trees can be propagated by budding or grafting sugar apple, custard apple, or pond apple (Annona glabra). Chip budding or veneer grafting are the two most successful methods $(1,2)$.

Both atemoya and sugar apple are intolerant of salty or freezing conditions, although mature trees may be able to withstand a few hours at subfreezing temperatures. The trees become leafless during periods of cold. Both plants are adapted to moderate, evenly distributed rainfall. Leaf shedding is a mechanism used by both species to withstand periods of drought. The trees grow and bear best on neutral, fertile soils. Trees should be spaced five to six $\mathrm{m}$ apart between and within rows. Pruning for sugar apple is needed to remove dead wood and broken branches. However, atemoya is pruned just prior to the growing period to promote an open-centered form with few main branches $(1,2)$ 
Atemoya is self fertile but individual flowers usually are not self-pollinated because stigmas are no longer receptive when the pollen is shed. Poor fruit set is a serious problem in some areas, evidently because of poor pollination. Incomplete pollination will also result in misshapen fruit. Those flowers that open during warm, humid weather are more likely to set fruit than those borne when conditions are dry and/or cold. Hand pollinating when the female flower first opens increases fruit set in these problem areas (1).

Atemoya and sugar apple are harvested numerous times (approximately 25) each year. They are generally harvested every third day for the first peak in August and September, and weekly for the second peak in October and November (4). Since mature fruit tend to split, they are harvested a few days prior to full maturity. Sugar apple are quite fragile, so they are sold locally. Atemoya can be held at temperatures as low as $13^{\circ} \mathrm{C}$ to facilitate shipment to market $(1,2)$.

\section{Insect/Mite Management}

\section{Insect/Mite Pests}

The principal pests on atemoya and sugar apple in Florida are annona seed borer and ambrosia beetles $(1,2)$.

\section{Annona Seed Borer (Bephratelloides} cubensis). This chalcidoid wasp was introduced into Florida in the 1920s. The female wasps lay eggs singly in small immature fruit. The larvae feed on seed endosperm and pupate within the seed. Adult wasps emerge by burrowing to the fruits exterior, which often leads to fungal infection and mummification of the fruit. The generation time for the wasp is about three months and the adults live no more than two weeks (5).
Both atemoya and sugar apple are attacked by this wasp. However, since atemoya blooms and fruits slightly earlier in the spring than sugar apple, it is generally infected at a higher rate than is sugar apple. Peak infestation rates for atemoya and sugar apple in southern Florida in late summer were approximately 80 and 20 percent, respectively. It is believed that the wasp overwinters in bullock's heart (Annona reticulata) and then attacks early season fruit, while late season fruit is attacked by newly emergent wasps (5).

Ambrosia Beetles (Family Scolytidae). Female ambrosia beetles bore into twigs, branches, or small trunks of susceptible woody plants, excavate a system of tunnels in the wood or pith, introduce the symbiotic ambrosial fungus, and produce a brood. The beetles feed on the fungus and stay with the brood until maturity. Males are rare, reduced in size, flightless, and presumably haploid. Females mate with their brother(s) before emerging to attack a new host. Most attacks on living plants are near ground level on saplings or at bark wounds on larger trees. Ambrosia beetles can attack a wide range of tropical fruit trees (6).

Young trees may be killed if numerous beetles try to colonize the tree. Isolated attacks are generally tolerated. However, cankers can form at the site of the isolated attacks, and eventually girdle the tree (6).

\section{Chemical Control}

In 1999-2000, 25 percent of responding surveyed atemoya and sugar apple growers reported insecticide use. Those survey respondents that provided insect damage estimates indicated that from 5 to 100 percent of the crop would be lost to insect damage $(n=5$, mean of 62 percent). 
Insecticides and miticides registered for use on atemoya and sugar apple in Florida include fenoxycarb (non-bearing trees), pymetrozine (Endeavor ${ }^{\circledR}$ - non-bearing trees), pyrethrin (Pyronyl® - atemoya only), pyrethrin plus rotenone (Pyrellin $\AA)$, methidathion (Supracide $\AA$ - sugar apple only), spinosad (SpinTor $\circledast$ ), insecticidal oil, kaolin (Surround $\AA$ ), insecticidal soap, Bacillus thuringiensis, azadirachtin, and Beauveria bassiana (Mycotrol $\left.{ }^{\circledR}\right)$.

Crop Oils. Crop oils work by smothering poorly mobile insects such as scales, aphids, and mites. The oils are usually made up as 1.5 to 3 percent solutions, which are applied thoroughly to each tree. Price varies greatly based on amount, formulation, and brand used. There is a four hour restricted entry interval (REI) for crop oils (7). In 1999-2000, 13 percent of surveyed atemoya and sugar apple growers in Florida applied crop oil twice per season.

Azadirachtin. Azadirachtin is a natural compound derived from the neem tree (Azadirachta indica) that has insect growth regulator as well as deterrent activity (8). The compound is used to manage lacewing bugs and mealy bugs. The price of azadirachtin is $\$ 2119.25$ per pound of active ingredient and the approximate cost per application is $\$ 92.14$ per acre $(9,10)$. The REI is 4 hours $(10)$. In 19992000, 13 percent of atemoya and sugar apple growers applied azadirachtin to their acreage twice a season.

\section{Alternative Control}

Several new "reduced impact" chemicals have been registered for use in atemoya and sugar apple. Mycotrol ${ }^{\circledR}$ (Beauveria bassiana) and kaolin (Surround $\AA$ ) are currently being assessed for insect management.

\section{Cultural Control}

Based on survey results of all tropical fruit growing respondents, 44 percent reported keeping records of pest problems, 50 percent adjusted applications (timing or rate) to protect beneficial insects and mites, and 52 percent alternated pesticides to reduce resistance. Sixty-two percent reported selecting the pesticide that is least toxic to beneficial insects and mites and 63 percent spot sprayed only infested plants or areas.

Seventy percent reported selecting pesticides that are least toxic to the environment to make this the dominant form of cultural pest control.

\section{Biological Control}

Seven percent of the responding tropical fruit growers reported release of predatory wasps for control of lepidopteran pests. Additionally, 30 percent reported the use of biological-derived pesticides like B.t.

\section{Weed Management}

\section{Weed Pests}

Weeds can reduce fruit yields by competing primarily for water and nutrients. Although individual weed species may vary from region to region within the state, predominant weed species in groves are grasses, sedges, and pigweeds (11). However, species composition is less important as the trend has been toward use of non-selective, post-emergent herbicides.

\section{Chemical Control}

In 1999-2000, 88 percent of surveyed atemoya and sugar apple growers reported herbicide use. Herbicides labeled for control of weeds in Florida for atemoya and sugar apple 
include glyphosate (Roundup ${ }^{\circledR}$ ), oxyfluorfen (Goal ${ }^{\circledR}$ - for sugar apple only), and pelargonic acid (Scythe $\left.{ }^{\circledR}\right)$.

Glyphosate (Roundup $\left.{ }^{\circledR}\right)$. Glyphosate is a phosphorylated amino acid herbicide used for total vegetation control (12). Glyphosate is applied as a directed spray so that foliage is not injured. The median price of glyphosate is $\$ 10.95$ per pound of active ingredient and the approximate cost per application is $\$ 21.90$ per acre for annual weeds and $\$ 54.75$ per acre for perennial weeds $(13,14)$. The REI for glyphosate is 12 hours (15).

In 1999-2000, 88 percent of surveyed atemoya and sugar apple growers in Florida applied glyphosate either three (14 percent), four (43 percent), five (14 percent), or six (29 percent) times for an average use of 4.6 times per season.

\section{Disease Management}

\section{Disease Pathogens}

The principal diseases affecting atemoya and sugar apple production in Florida include anthracnose (Colletotrichum gloeosporioides) and rust (Phakopsora cherimoliae). Fungal diseases which are non-manageable (removal and destruction) include mushroom root rot (Armillaria tabescens) and Pythium root rot $(16,17)$.

Anthracnose (caused by Colletotrichum gloeosporioides). This fungus infects flowers, leaves, and fruit. Infected flowers develop dark lesions on the petals that enlarge and cause flower blackening and death. Young fruit that are infected will rot and mummify on the tree. When the fungus invades mature fruit, the resultant lesion is small and relatively cosmetic with a shallow area of hardened tissue. Infected leaves develop light green lesions that enlarge into irregular brown areas, giving the leaves a scorched appearance. It can also cause premature leaf drop (16).

Rust (caused by Phakopsora cherimoliae). This fungus infects leaves during the summer through fall. Slightly yellow spots develop in response to the infection. The fungus reproduces rapidly in the form of a slightly raised pustule or blister. Severe levels of infection can cause defoliation (16).

\section{Chemical Control}

In 1999-2000, 63 percent of surveyed atemoya and sugar apple growers reported fungicide use. Those survey respondents that provided damage estimates indicated that from 10 to 100 percent of the crop would be lost to disease ( $n=4$, mean of 55 percent). Fungicides registered for use on atemoya and sugar apple include copper hydroxide/sulfate (Kocide ${ }^{\circledR} /$ Basicop ${ }^{\circledR}$ ) and Trichoderma harzianum (Rootshield ${ }^{\circledR}$ ).

Copper (Kocide ${ }^{\circledR} /$ Basicop $\left.{ }^{\circledR}\right)$. Copper has long been used as a fungicide and can be applied in multiple forms (copper hydroxide, copper sulfate, etc.). Copper is primarily used in an attempt to manage anthracnose. The median price of copper hydroxide is $\$ 2.11$ per pound of active ingredient. For atemoya, the approximate cost per application is $\$ 4.87$ per acre. The cost per acre for sugar apple is $\$ 19.48(13,18)$. The REI for copper hydroxide/copper sulfate is 24 hours (18).

In 1999-2000, 63 percent of surveyed atemoya and sugar apple growers in Florida applied copper. Copper was applied either one (40 percent), two (20 percent), three ( 20 percent), or four (20 percent) times for an average use of 2.2 times per season. 


\section{Alternative Control}

Several new "reduced impact" chemicals have been registered for use in atemoya and sugar apple. Based on work by IR-4, tolerances for azoxystrobin and mefenoxam were obtained in the fall of 2001. These materials will assuredly be assessed for disease management in these crops.

\section{Nematode Management}

\section{Nematode Pests}

Plant-parasitic nematodes are microscopic roundworms, found in soils, which primarily attack plant roots. General signs of nematode damage include stunting, premature wilting, leaf yellowing, root malformation, and related signs characteristic of nutrient deficiencies. Stunting and poor stand development tends to occur in patches throughout the grove as a result of the irregular distribution of nematodes within the soil.

\section{Chemical Control}

There are no nematicides registered for use on atemoya or sugar apple in Florida. None of the surveyed growers reported the use of nematicides.

\section{Key Contacts}

- Jonathan Crane is an associate professor of horticultural science located at the Tropical Research and Education Center in South Florida. He is responsible for research and extension duties associated with tropical fruit. Dr. Crane can be reached at: TREC, 18905 SW $280^{\text {th }}$ St., PO Box 111569, Homestead, FL 330313314, (305) 246-7001, jhcr@gnv.ifas.ufl.edu.
- Michael Aerts is the assistant director of the Environmental and Pest Management Division of the Florida Fruit and Vegetable Association. He facilitates communication between commodity groups and regulatory agencies. Mr. Aerts can be reached at: FFVA, $4401 \mathrm{E}$. Colonial Drive, Box 140155, Orlando, FL 32814, (407) 894-1351, maerts@ffva.com.

- Mark Mossler is a pesticide information specialist for the Food Science and Human Nutrition Department's Pesticide Information Office at the University of Florida's Institute of Food and Agricultural Sciences. He is responsible for providing pesticide information to the public and governmental agencies. Mr. Mossler can be reached at UF/IFAS PIO, Box 110710, Gainesville, FL 32611, (352) 392-4721, mamossler@mail.ifas.ufl.edu

\section{Acknowledgements}

The following individuals served as reviewers and/or provided information used in the atemoya and sugar apple profile:

- Carlos F. Balerdi, Extension Agent III, Fruit Crops, Multi-County, Dade County, Homestead;

- Robert T. McMillan Jr, Professor, Subtropical Fruits and Vegetables, University of Florida, Tropical Reseach and Education Center, Homestead;

- Jorge E. Peña, Professor, Tropical Fruit Entomology, University of Florida Tropical Research and Education Center, Homestead; 
Support for Florida's Crop/Pest Management Profile project and this publication was provided by a Pest Management Centers grant from the USDA-CSREES.

\section{References}

1. Campbell, C.W. and Phillips, R.L. April 1994. The Atemoya. Horticultural Sciences Department Fact Sheet HS-64. Florida Cooperative Extension Service, Institute of Food and Agricultural Sciences, University of Florida. Available: http://edis.ifas.ufl.edu/MG332

2. Campbell, C.W. and Phillips, R.L. April 1994. The Sugar Apple. Horticultural Sciences Department Fact Sheet HS-38. Florida Cooperative Extension Service, Institute of Food and Agricultural Sciences, University of Florida. Available: http://edis.ifas.ufl.edu/MG330

3. Degner, R.L., Moss, S.D., and Mulkey, W.D. August 1997. University of Florida, Institute of Food and Agricultural Sciences Report: Economic Impact of Agriculture and Agribusiness in Dade County, Florida. Florida Agricultural Market Research Center Industry Report 97-1. Gainesville, FL.

4. Personal communication, Jonathan Crane, Tropical Research and Education Center, Homestead, FL. August, 2001.

5. Nadel, H. and Peňa, J.E. August 1991. Seasonal Oviposition and Emergence Activity of Bephratelloides cubensis (Hymenoptera: Eurytomidae), a Pest of Anonna Species in Florida. Environ. Entomol. 20(4), 1053-1057.

6. Atkinson, T.H., Foltz, J.L., Wilkinson, R.C., and Mizell, R.F. June 2000. Asian Ambrosia Beetle. Department of Entomology and Nematology, University of Florida, and Florida Department of Agriculture and Consumer Services, Division of Plant Industry Featured Creatures Web site.
Available:

http://creatures.ifas.ufl.edu/trees/asian_ambro sia beetle.htm

7. Knapp, J.L. October 2000. 2001 Florida Citrus Pest Management Guide: Pesticides Registered for Use on Florida Citrus. Fact Sheet ENY-601. Florida Cooperative Extension Service, Institute of Food and Agricultural Sciences, University of Florida. Available: http://edis.ifas.ufl.edu/CG017

8. Thomson, W.T. 2001. Agricultural Chemicals Book I Insecticides. Thomson Publications, Fresno, CA.

9. Personal communication with Helena Chemicals, Alachua, FL. July, 2001.

10. Certis labels. Available: http://www.cdms.net/manuf/mprod.asp? $\mathrm{mp}=8$ $\underline{9 \& 1 \mathrm{c}=0}$

11. Knapp, J.L. February 1999. Citrus Commodity: A Biologic and Economic Assessment of Pesticide Usage. USDA National Agricultural Pesticide Impact Assessment Program Report No. 1-CA-99.

12. Weed Science Society of America. 1994. Herbicide Handbook - $7^{\text {th }}$ Edition.

13. DPRA. March 2001. AGCHEMPRICE, Current U.S.A. Prices of Non-Fertilizer Agricultural Chemicals. Summary Edition. DPRA Incorporated, Manhattan, KS.

14. Futch, S.H. and Singh, M. October 2000. 2001 Florida Citrus Pest Management Guide: Weeds. Fact Sheet HS107. Florida Cooperative Extension Service, Institute of Food and Agricultural Sciences, University of Florida. Available: $\underline{\text { http://edis.ifas.ufl.edu/CG013 }}$

15. Monsanto Company labels. Available: http://www.cdms.net/manuf/mprod.asp? $\mathrm{mp}=2$ $\underline{3 \& 1 \mathrm{c}=0}$ 
16. Simone, G.W. June 1999. Disease Control in Atemoya (Annona cherimola $x$ A. squamosa).

Florida Cooperative Extension Service,

Institute of Food and Agricultural Sciences, University of Florida. Available:

http://edis.ifas.ufl.edu/PG112

17. Aflieri, S.A., Langdon, K.R., Wehlburg, C., and Kimbrough, J.W. 1984. Index of Plant Diseases in Florida. Florida Department of Agriculture \& Consumer Services, Division of Plant Industry Bulletin 11.

18. Griffin labels. Available:

http://www.cdms.net/manuf/mprod.asp? $\mathrm{mp}=1$ $\underline{4 \& 1 \mathrm{c}=0}$ 